\title{
Ceramic micropalaeontology: the analysis of microfossils in ancient ceramics
}

\author{
PATRICK S. QUINN \& PETER M. DAY \\ Department of Archaeology, University of Sheffield, Northgate House, West Street, Sheffield S1 4ET, UK \\ (e-mail: patrick.quinn@sheffield.ac.uk; p.m.day@sheffield.ac.uk)
}

\begin{abstract}
Microfossils can be a common component of ancient ceramic artefacts. Their analysis in this unusual context is a little-known, yet promising, cross-disciplinary application of micropalaeontology. This article presents the first detailed assessment of the phenomenon of microfossils in ancient ceramics and demonstrates how micropalaeontology can contribute to a range of issues in archaeological ceramic analysis and the reconstruction of the human past. In describing a methodology by which micropalaeontologists and archaeologists can analyse microfossiliferous ceramics, this paper presents the foundations of an approach, which is here referred to as 'ceramic micropalaeontology'. J. Micropalaeontol. 26(2): 159-168, October 2007.
\end{abstract}

KEYWORDS: archaeology, ancient ceramics, provenance, technology, applied micropalaeontology

\section{INTRODUCTION}

Microfossils occur in a wide range of often surprising archaeological contexts including prehistoric building materials (Thomsen, 1983), statues (Fiorentino, 1998), paintings (Svábenická, 1995), ceramics (Quinn et al., 1998), stone tools (Brooks \& Dorning, 1997), baskets (Bryant \& Morris, 1986), ancient fuel (Smith, 1997), fossil faeces (Horrocks et al., 2002), shipwrecks (Vourela, 1994), human remains (Leroi-Gourhan, 1975), as well as the earthy strata of archaeological sites (Groenman-van Waateringe \& Jansma, 1968). The application of micropalaeontological techniques to these unconventional assemblages can be a useful interdisciplinary enterprise. By integrating archaeological and micropalaeontological data, it is possible to address a range of important questions about human behaviour in the past (Quinn, 1997a).

Archaeological ceramics, as argillaceous sedimentary material that has been processed and fired, can contain microfossils of many types (Fouqué, 1879; Farnsworth, 1964; Jansma, 1984; Hunt, 1996; Troja et al., 1996; Håkansson, 1997; Ghosh et al., 2006). Whilst archaeologists are often aware of the presence of microfossils in this context, detailed micropalaeontological analyses of ancient ceramics are not common. Given the level of biostratigraphical and palaeoenvironmental information that micropalaeontology can elucidate, microfossil assemblages, where present, have a great deal to offer the analysis of ancient ceramics.

This paper details this little-known phenomenon of microfossils in archaeological ceramics and outlines a methodology by which they can be studied. By bringing together the disparate strands of micropalaeontological work on ancient ceramics and presenting some of the authors' own research from the Bronze Age and later periods of the Mediterranean (Quinn et al., 1998; Day et al., 1999a; Quinn, 1999; Quinn \& Day, 2007), it is demonstrated that, when combined with stylistic, petrological and chemical data from ceramics, micropalaeontology can be used to further the aims of archaeological ceramic analysis - the determination of origin or provenance and the reconstruction of ancient ceramic technology. The direct application of microfossil analyses in this way forms a very promising area of applied research, which is called here 'ceramic micropalaeontology' (Quinn, 1997b).
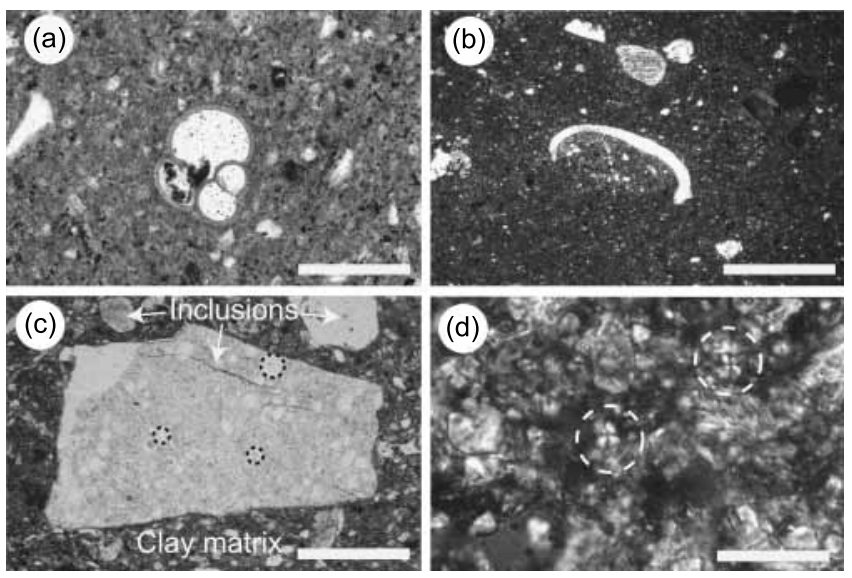

Fig. 1. Microfossils in thin sections of archaeological ceramics: (a) planktic foraminifer in plane polarized light (PPL), scale bar $=200 \mu \mathrm{m}$; (b) ostracod valve in crossed polars, scale bar $=500 \mu \mathrm{m}$; (c) radiolaria within a chert inclusion in PPL (circles), scale bar $=200 \mu \mathrm{m}$; (d) calcareous nannofossils at very high magnification in crossed polars (circles), scale bar $=20 \mu \mathrm{m}$.

\section{OCCURRENCE OF MICROFOSSILS IN ANCIENT CERAMICS}

The occurrence of microfossils in archaeological ceramics has been known for some time (e.g. Fouqué, 1879; Davis, 1951). Archaeologists often study the mineralogical and petrological composition of ceramic thin sections at magnifications of $\times 25$ to $\times 400$ under the polarizing light microscope. This approach is called ceramic petrography and has been responsible for the majority of observations of microfossils in ancient ceramics, including foraminifera (Fig. 1a) (Fouqué, 1879; Einfalt, 1978; Williams, 1978; Riley, 1981, 1982, 1983; MacGillivray et al., 1988; Vaughan, 1990; Day, 1995; Vaughan et al., 1995; Montana et al., 2003), ostracods (Fig. 1b) (Day et al., 1999a), diatoms (Håkansson \& Hulthén, 1986; 1988; Håkansson, 1997), radiolaria (Fig. 1c) (Farnsworth, 1964; Whitbread, 1995) and silicoflagellates (Håkansson, 1997).

Microfossils can occur in several different contexts within ancient ceramics. The precise context in which they occur is important in terms of the type of information that they can 


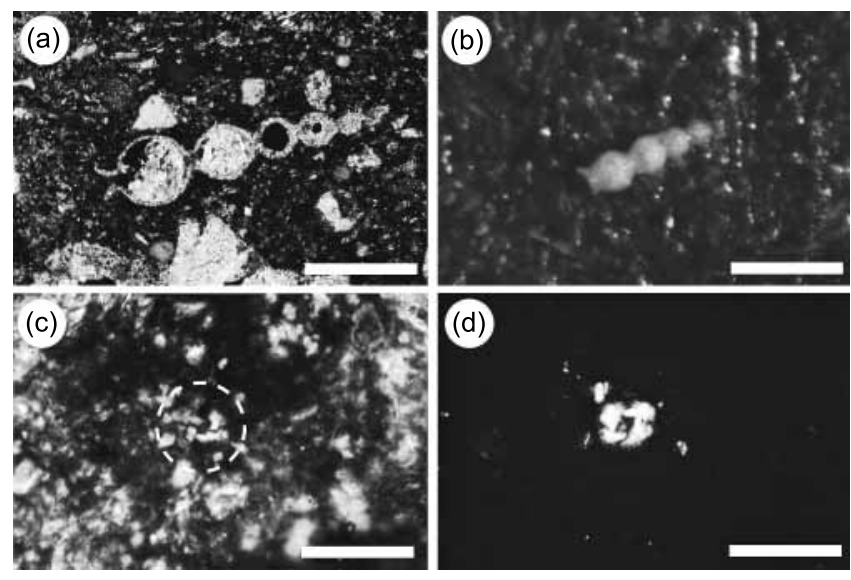

Fig. 2. Methods of studying microfossils in ceramics: (a) benthic foraminifer Stilostomela adolphina in thin section, crossed polars, scale bar $=200 \mu \mathrm{m}$; (b) isolated benthic foraminifer Stilostomela adolphina in picked slide, scale bar $=250 \mu \mathrm{m}$; (c) calcareous nannofossil Reticulofenestra pseudoumbilica in thin section (circle), crossed polars, scale bar $=20 \mu \mathrm{m}$; (d) isolated calcareous nannofossil $R$. pseudoumbilica in smear slide, scale bar $=20 \mu \mathrm{m}$.

offer. Microfossils present in the raw clays used for pottery making will normally appear in the clay matrix of archaeological ceramics (Figs 1a-b, d). Solid particulate matter added to a wet clay body as a filler or temper, may also contain microfossils. This can be limestone, chert (Fig. 1c), or even crushed ceramic (grog). Allochthonous microfossil specimens such as airborne pollen can be incorporated unintentionally into the body of a ceramic during its production. Decorative coatings (slips) and paints added to the exterior of a vessel can also contain microfossils, particularly if they were prepared from sedimentary raw materials of marine origin.

The occurrence of microfossils in archaeological ceramics is perhaps surprising given that they are intentionally fired at high temperatures. Firing is one of a range of processes during the life history of ceramic vessels that can potentially affect the quality of the microfossil assemblages that they contain (Quinn, 1999). These processes include the intentional mixing of raw materials containing different microfossil assemblages during ceramic manufacture, the unintentional contamination of microfossil assemblages at various stages in the ceramic production process, the modification of microfossil assemblages as a consequence of the use of ceramic artefacts, as well as the diagenetic alteration of microfossils during the burial of ceramics in the archaeological record.

\section{METHODS OF STUDYING MICROFOSSILS IN ANCIENT CERAMICS}

Ceramic thin sections, prepared for petrological analysis, represent the most convenient means of detecting the presence of microfossils in ancient ceramics. Whilst it may be possible to identify favourably orientated individuals to genus or even species level in thin section (Fig. 2a), in most cases key features, such as pore structures in foraminifera or muscle scars in ostracods, are not well represented. An additional limitation of studying microfossils in thin section is the low abundance of specimens. Ceramic thin sections are typically between $1 \mathrm{~cm}^{2}$ and $10 \mathrm{~cm}^{2}$ in size and rarely contain more than a few individuals of larger microfossils, such as foraminifera or diatoms.

Luckily, most groups of microfossils can be isolated successfully from samples of fired ceramics using standard micropalaeontological techniques. Complete specimens of foraminifera (Fig. 2b) (Davis, 1951; Quinn \& Day, 2007), diatoms (Gibson, 1983; Håkansson \& Hulthén, 1986; Jansma, 1990), silicoflagellates (Håkansson, 1997) and palynomorphs of several kinds (Magid \& Krzywinski, 1988, Hunt, 1996; Ghosh et al., 2006) have been liberated from small pieces of archaeological ceramics by mechanical and chemical treatment. The drawback of such an approach is that it is highly destructive and can therefore be applied only to sherds of lesser archaeological importance.

Isolating complete microfossil specimens seems to be the only practical method of analysing siliceous microfossils and palynomorphs in detail in ceramics. The transparent thecae of diatoms are usually obscured by the clay matrix in thin sections of ceramics, which can present significant difficulties for their taxonomic identification (Håkansson \& Hulthén, 1986; Håkansson, 1997). Studies of diatoms from ceramics have therefore concentrated on assemblages digested from small numbers of often un-diagnostic sherds.

Because of the extremely small size of calcareous nannofossils $(<10 \mu \mathrm{m})$ in comparison to the thickness of thin sections $(30 \mu \mathrm{m})$, they can often be observed as complete specimens in archaeological ceramics under the microscope (Fig. 2c). A more convenient method of studying calcareous nannofossils in archaeological ceramics, however, is to prepare smear slides from the original artefacts themselves (Quinn et al., 1998; Quinn \& Day, 2007) (Fig. 2d).

Thin sections provide a useful means of assessing the contexts in which microfossils occur in archaeological ceramics and should be used, wherever possible, to complement digested micropalaeontological residues or calcareous nannofossil smear slides. An appreciation of the occurrence and distribution of microfossil specimens in thin section can help to place detailed microfossil analyses in context and add meaning to subsequent interpretations.

\section{MICROPALAEONTOLOGY AND THE DETERMINATION OF CERAMIC PROVENANCE}

A major concern in the study of archaeological ceramics is the determination of their origin or provenance. The geographical source location of ceramic artefacts allows archaeologists to explore a range of important themes, including the relationships between different settlements or societies in the past, the existence of trade and exchange networks, the organization of ceramic production, and even choices made by ancient potters. As a starting point, ceramic analysis records the petrological or chemical composition of archaeological ceramics and compares this to local and regional geology and the nature of ceramic reference groups of known origin.

Microfossils can be used in several ways to assist in the determination of ceramic provenance. On a very basic level, the presence of broad groups of microfossils alongside other distinctive inclusions in thin section may be sufficient to relate ancient ceramics to specific deposits of raw materials. For example, Whitbread (1995) noted radiolaria within inclusions of crushed chert temper in Greek amphorae from Corinth and linked these 


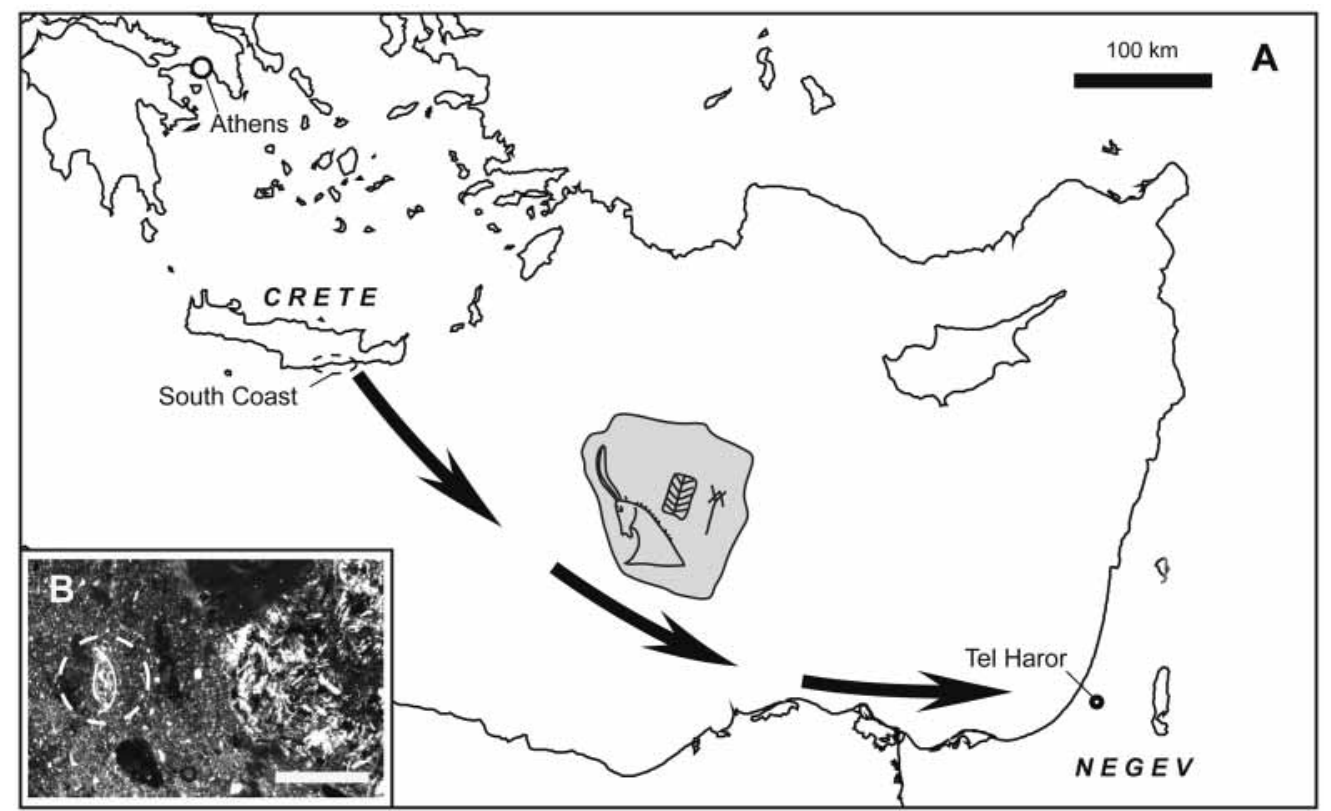

Fig. 3. Provenance of the Tel Haror Inscribed Sherd: (a) location of the site of Tel Haror and likely provenance of the inscribed sherd in southern Crete (sherd re-drawn after Day et al., 1999a); (b) composition of the Tel Haror sherd in thin section, with large basic igneous inclusion (right) and an ostracod specimen (circle), scale bar $=500 \mu \mathrm{m}$.

to a nearby outcrop of radiolarite, providing strong evidence for the local production of ceramics at or around the site during the first millennium BC. In favourable circumstances, the presence of specific microfossil groups in thin section may also be used to indicate the long distance movement of non-local or imported ceramics in the past. A good example comes from our analysis of a single distinctive sherd excavated from Bronze Age levels at the site of Tel Haror in the Negev Desert, Israel (Day et al., 1999a) (Fig. 3a).

The Tel Haror Sherd bears a hieroglyphic inscription, including a bull's head, which resembles inscriptions in Crete (Fig. 3a) and therefore, determining the origin of the vessels from which the sherd came is of great importance. In thin section it is characterized by the presence of two main types of inclusions rounded coarse grains of basic igneous rocks and ostracods (Fig. 3b). Initial compositional analyses of the sherd suggested that it is incompatible with the local geology of the western Negev, or other Israeli ceramics (Oren et al., 1996). Epigraphical and typological studies both suggest that it may have come from Crete and subsequent comparison of its fabric with thin sections of Bronze Age ceramics from various archaeological sites on the island suggested a possible match.

The presence of rounded basic igneous inclusions, added as sand temper, is a common characteristic of ceramics from several parts of Crete in the Bronze Age. However, the occurrence of these inclusions alongside ostracod specimens has, as yet, been reported only from a few sites on the central south coast of the island (Fig. 3a). Because of the small size and archaeological importance of the Tel Haror Sherd, the authors were unable to isolate microfossil specimens for detailed taxonomic identification. However, the striking compositional similarity between this sherd and Bronze Age "South Coast" pottery fabrics in Crete (Whitelaw et al., 1997; Day et al., 1999b) suggests that it was probably produced from similar materials in the same source area, east of Ierapetra on the south coast of Crete. The sherd, which seems to have once been part of a large storage vessel, therefore, provides further strong evidence for maritime connections between Crete and the Levant during the Middle Bronze Age in the second millennium BC (Fig. 3a).

The biostratigraphical interpretation of microfossil assemblages in archaeological ceramics provides a more reliable means of determining the source of ancient artefacts. By using microfossils to date the geological age in which the raw clays or temper used in the manufacture of ancient ceramics were formed and relating this to the geographical extent of contemporaneous deposits, it can be possible to make confident interpretations of origin and even pin-point the exact raw materials used by potters in the past. A biostratigraphical approach to provenancing archaeological ceramics has been adopted in this analysis of Early Bronze Age ceramics from various sites on Crete. Calcareous, microfossiliferous, shallow-marine sediments are common on Crete and it is now clear that these clays, marls and limestones were utilized in the past by Cretan potters (Hein et al., 2004), resulting in the occurrence of microfossils in archaeological ceramics from numerous sites on the island.

One archaeological site that has unearthed significant quantities of microfossiliferous ceramics is Myrtos Fournou Korifi on the south coast of Crete (Figs $4 a-b$ ). Some $47 \%$ of the ceramic artefacts excavated from the final occupation level of this site belong to the South Coast ceramic fabrics mentioned above (Fig. 4c). This stylistic and compositional group of ceramics is also found at other sites along the central south coast of Crete and may have been produced at a single location in this area using Neogene clays and water-worn sand derived from basic igneous rocks. Both of these raw materials occur in abundance in the south coast area, where Neogene sediments are common and river and beach sand derived from the erosion of the pre-Neogene basement rocks can be found (Fig. 4a). The 


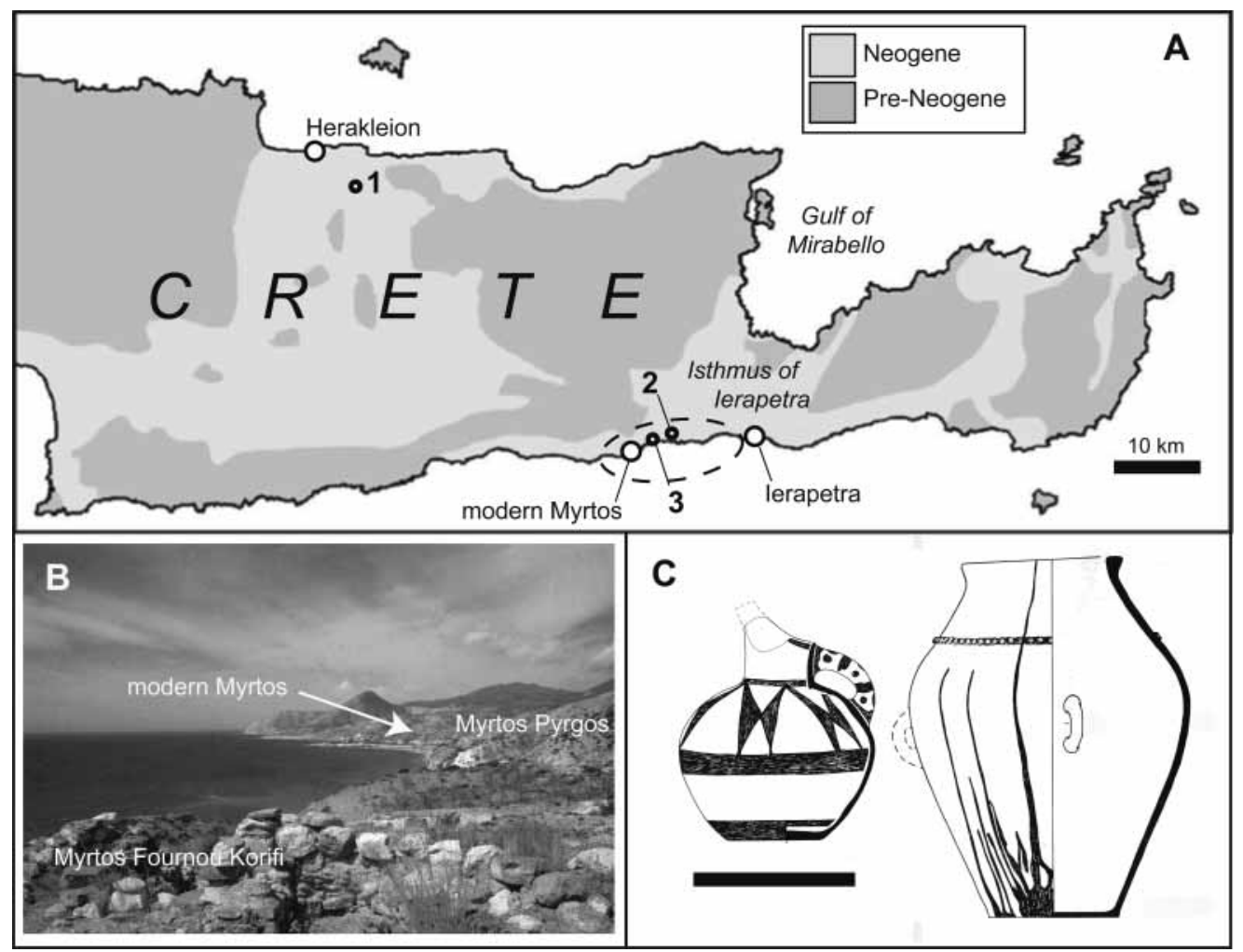

Fig. 4. Myrtos Fournou Korifi and the Early Bronze Age South Coast ceramics. (a) Map of Crete showing the location of the archaeological sites of Knossos (1), Myrtos Fournou Korifi (2) and Myrtos Pyrgos (3), the suspected origin of the South Coast ceramics (dashed line) and the extent of microfossiliferous Neogene sediments and pre-Neogene basement rocks (shading).(b) The ancient settlement of Myrtos Fournou Korifi. (c) Ceramic vessels from the South Coast production group (after Warren, 1972). Scale bar $=25 \mathrm{~cm}$.

frequent occurrence of this distinctive ceramic recipe at the Early Bronze Age sites of Fournou Korifi and Pyrgos, near the modern village of Myrtos, and the discovery of eight clay discs at Fournou Korifi, thought to be potters turntables (Warren, 1969), add weight to arguments that the South Coast ceramics may have been manufactured somewhere in the Myrtos area. However, it has not been possible to confirm or disprove this theory based upon the petrography of the ceramics alone, as both Neogene deposits and sand are common throughout the area. In order to investigate the provenance of the South Coast fabrics in more detail, the microfossil assemblages were analysed from selected South Coast ceramic sherds of Myrtos Fournou Korifi and Myrtos Pyrgos, along with material from a number of other contemporary sites (Quinn \& Day, 2007).

In thin section, the microfossil assemblages of the South Coast ceramic samples were characterized by foraminifera and ostracods. It was possible to broadly identify specimens of benthic foraminifera in some samples. However, for comparison, complete foraminifera were isolated from a single sherd that was particularly rich in microfossils. The presence of planktic foraminifera such as Globorotalia subscitula, dwarfed specimens of Globigerina acostaensis and abundant Sphaeroidinellopsis indicated that it was probably manufactured with a component of Early Pliocene raw materials (Zachariasse, 1975; Spaak, 1983). Calcareous nannofossil smear slides prepared from this and other South Coast ceramics, according to the method described above, corroborated the biostratigraphical assignment of the foraminifera. By comparison with the
Mediterranean Pliocene zonation scheme of Driever (1988), the calcareous nannofossil assemblages of the South Coast ceramics were ascribed to subzone NN12-13B (equivalent to early NN13 of Martini (1971)) (Fig. 5a).

In order to compare this biostratigraphical assessment of the South Coast ceramic samples with the Neogene geology of the south coast region of Crete, representative geological field samples were collected and analysed for calcareous nannofossils. The Neogene marine sediments of the south coast of Crete are subdivided into several formations deposited during latest Middle Miocene to Early Pliocene times (Fortuin, 1977; Vidakis et al., 1993). The youngest Neogene sediments of this area are the light-coloured Early Pliocene marls of the Myrtos Formation (Fig. 5b). This unit has a restricted distribution along the south coast and occurs mostly as heavily tectonized, gypsiferous marl breccia, which is not a suitable raw material for ceramic production (Fig. 5b). However, there are isolated, more suitable occurrences of undisturbed, homogeneous and laminated Early Pliocene marls of the Myrtos Formation, including one on the hill upon which the village of Myrtos Fournou Korifi once stood (Figs $5 b-c$ ), as well as other nearby deposits further to the east. These sediments are strong candidates for the source of the microfossiliferous raw materials exploited for the manufacture of the main local fabrics found at Myrtos Fournou Korifi and other sites in this area.

It therefore appears that the distinctive ceramics of the South Coast production group were manufactured by Early Bronze Age potters from the locally available Myrtos Formation marls, 


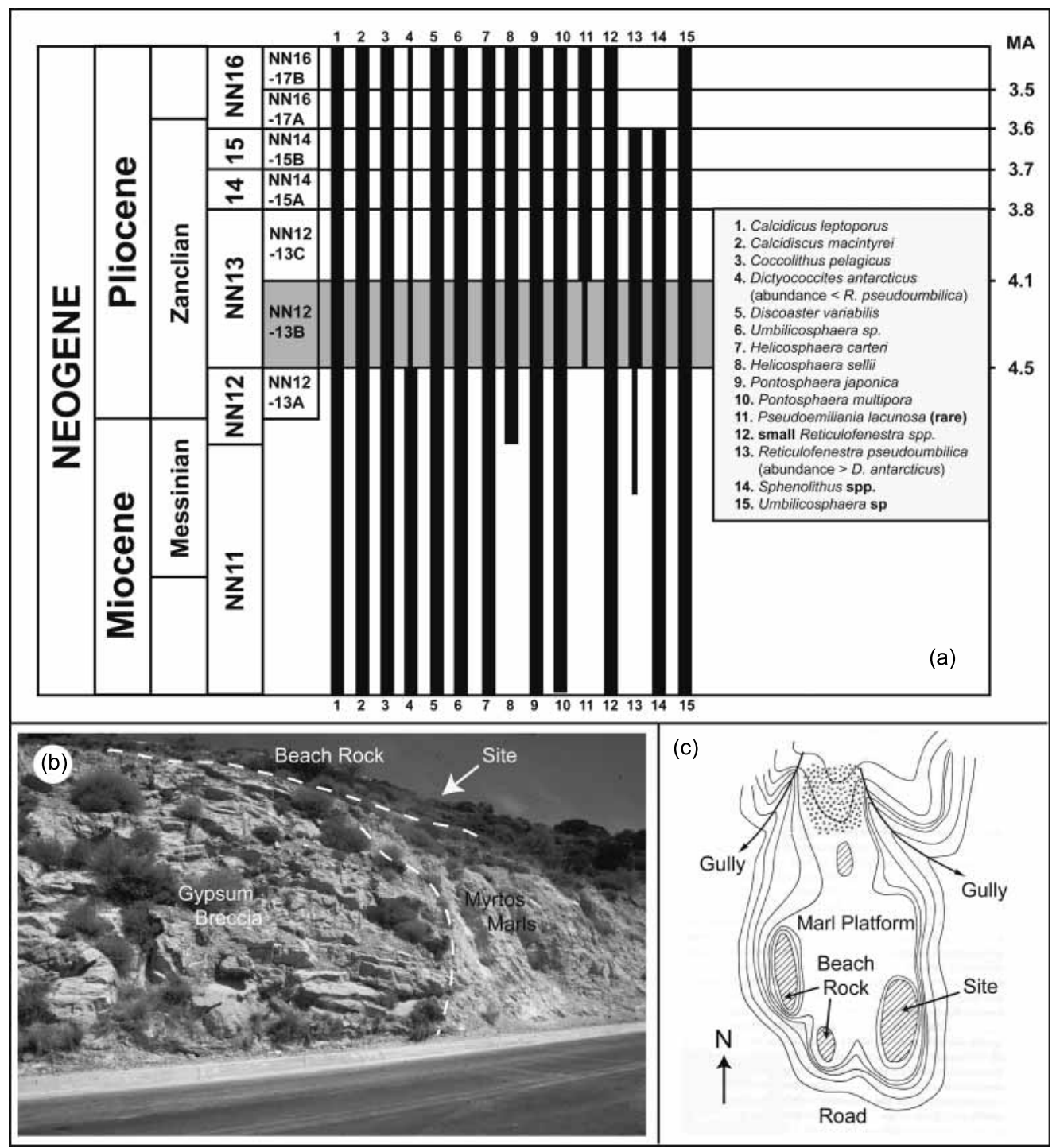

Fig. 5. Biostratigraphical microprovenance interpretation of the Early Bronze Age South Coast ceramics from Myrtos Fournou Korifi. (a) Biostratigraphical assignment of calcareous nannofossils from representative South Coast ceramic sample (shaded area) against standard nannofossil zonation scheme of Martini (1971) (NN 11-16) and the Pliocene Mediterranean nannofossil zonation scheme of Driever (1988) (NN 12-13A-NN 16-17B). (b) Outcrop of Myrtos Formation marls and breccia close to the site of Myrtos Fournou Korifi. (c) Plan of the site of Myrtos Fournou Korifi (modified from Warren, 1972).

in combination with rounded river or beach sand. These two components were mixed in varying amounts to produce a range of clay pastes, which were formed by hand and finished using a turntable. This interpretation of the South Coast ceramics demonstrates how several different lines of evidence, including micropalaeontology, can be combined to provide a picture of ceramic production in the past. By applying microfossil biostratigraphy within an archaeological and petrographical framework, it has been possible to identify specific candidate deposits of Neogene raw materials used by Bronze Age potters.

Other studies in which the biostratigraphical interpretation of microfossil assemblages has been used to pin-point the precise sources of raw materials used in ancient ceramic production, includes work on sites in Sicily by Troja et al. (1996), Alaimo et al. (1997) and Quinn et al. (1998). In the latter example, calcareous nannofossils were studied from ancient ceramics and probable storage deposits of unused raw materials at a Punic (5th-6th century BC) workshop on the island of Mozia. The Punic ceramics from this workshop contained mixed calcareous nannofossil assemblages with specimens of Early Cretaceous, Late Cretaceous, Late Paleocene, Late Eocene-Early Miocene, Early Pliocene and possibly Pleistocene age, in individual samples. These assemblages matched that of the raw materials stored near the ancient kiln. For comparison, field samples from a nearby stream were also analysed - it could have represented a suitable local source of clay for the workshop. The calcareous nannofossil assemblage of these clays was represented by a comparable range of reworked specimens of various ages, transported from further upstream. The close correlation between the nannofossil assemblages of river clays, the ceramics and the unused raw materials suggests that they have a similar origin. It was, therefore, possible to conclude that the potters 
working at the workshop on Mozia utilized locally available raw materials for the production of ceramics in Punic times.

Another way in which micropalaeontology can contribute to the determination of provenance is through the palaeoenvironmental interpretation of microfossil assemblages occurring in ancient ceramics. By characterizing sherds in terms of the palaeoenvironment in which their raw materials were deposited and referring to field samples, geological reports and maps that document the extent of specific sedimentary facies, it can be possible to trace the origin of archaeological ceramics on several scales.

The salinity analysis of Quaternary diatom floras from ancient ceramics in northwest Europe has been used in a range of studies to interpret provenance in this way (Foged, 1968; Edgren, 1970; Jansma, 1977, 1981, 1984, 1990; Alhonen \& Matiskainen, 1980; Alhonen et al., 1980; Alhonen \& Väkeväinen, 1981; Gibson, 1983; Matiskainen \& Alhonen, 1984; Stilborg, 1997). On a simple level, several analyses have used the distinction between ceramics containing salinity tolerant (polyhalobous) diatoms that were produced from marine clays and those with salinity intolerant (oligohalobous) diatoms from freshwater environments, to distinguish between local and nonlocal ceramics at coastal sites in the Netherlands and Denmark (e.g. Jansma, 1984; Stilborg, 1997). In these examples, sherds characterized by marine diatoms were assumed to have been produced locally and those samples containing freshwater diatom floras were thought to have been manufactured inland and imported to the coast.

A more reliable approach is to compare the diatom floras isolated from ceramics to that of possible sources of raw materials as demonstrated by Jansma (1977) and Alhonen \& Matiskainen (1980). In the latter study, Neolithic ceramics, excavated from six sites on the Finnish archipelago of Aland, were found to contain dominantly freshwater diatom species including Melosira arenaria and $M$. islandica. By comparing in detail the diatom floras of the Early Comb Ware ceramics to the late Quaternary and Holocene sedimentary sequence of Finland, Alhonen \& Matiskainen (1980) discovered that they were equivalent to the flora of the Ancylus Formation, which was deposited during a freshwater episode of the Baltic Sea (Alhonen, 1971; 1979). Ancylus clays do not occur on the Åland Islands, but are common on the Finnish mainland and appear to have been used as a raw material for Neolithic ceramics at other archaeological sites (Alhonen \& Väkeväinen, 1981). During the Neolithic, the Åland archipelago consisted of but a few small islands and was populated by seal-hunting populations. It therefore appears that these Neolithic inhabitants brought Comb Ware ceramics with them from the mainland to the Aland Islands in Neolithic times or were engaged in maritime trade with other Finnish settlements.

\section{MICROPALAEONTOLOGY AND THE RECONSTRUCTION OF CERAMIC TECHNOLOGY}

In addition to the determination of origin or provenance, another important theme in archaeological ceramic analysis is the reconstruction of the technology used in the manufacture of ancient ceramic artefacts. Ceramic technology is of interest to the archaeologist as a means of studying the craft practices and knowledge, from an appreciation of past mastery of raw materials, to detailing the spread and evolution of such practices and technological know-how through space and time. Like provenance, details of technological practice are reflected in the composition of archaeological ceramics at the microscopic level. Ceramic technology can be conveniently broken down into the successive steps involved in the transformation of raw materials to finished ceramic artefact, including the mixing of different clays, vessel forming and decoration. As common microscopic components of many ceramics, microfossils have the potential to contribute to the understanding of ceramic technology, particularly in terms of methods of ceramic paste preparation and the technology of ancient firing.

After the selection and procurement of suitable raw materials, one of the first steps in the production sequence of archaeological ceramics was to process them to produce a suitable clay body. In the past, as in the present day, potters often mixed different types of clays and added solid particulate temper to produce a workable clay paste. Detecting these actions and characterizing the nature of the different components of a clay recipe is an important source of technological information. The analysis of microfossils in archaeological ceramics has been used in several ways to decipher the nature of paste preparation. The presence in single sherds of microfossils of conflicting geological ages or environmental tolerances has been interpreted as evidence for both clay mixing (Jansma, 1977; Matiskainen \& Alhonen, 1984; Hunt, 1996) or the addition of temper (Jansma, 1981, 1984). However, as highlighted by the micropalaeontological analysis of Punic artefacts from the island of Mozia (Quinn et al., 1998), mixed microfossil assemblages in ceramics can also result from the exploitation of river clays containing reworked material.

In a study of Middle Bronze Age ceramics from the site of Knossos on Crete, calcareous nannofossil analysis was combined with petrographic observations of thin sections to address the subject of paste preparation (Quinn \& Day, 2007). The ceramics, a distinctive group of small containers or pyxides, were found to contain well-preserved Early Pliocene calcareous nannofossil assemblages, which are compatible with the lightcoloured microfossiliferous Early Pliocene marls of the Finikia Formation, in north-central Crete, as well as in other areas of Crete. However, field observations of these highly calcareous sediments suggest that they have a poor workability and are therefore not suitable for the manufacture of ceramics (Day, 1989). Nevertheless, by studying thin sections of the Knossian pyxides, it was observed that planktonic foraminifera and calcareous nannofossils occurred within distinct calcareous marly inclusions and as discrete inclusions in the clay-rich matrix of the ceramics (Fig. 6). Similar microfossil specimens occurred in both of these contexts, suggesting that they had the same origin. The good state of preservation of the foraminifera and the absence of reworked specimens in the calcareous nannofossil assemblages ruled out the possibility that a single naturally mixed source, such as a river clay or a slopewash deposit, could have been used in the production of these ceramics. It therefore appears that the Middle Bronze Age Knossian pyxides were produced by the mixture of a clay-rich sediment with the highly-calcareous microfossiliferous marls of the Early Pliocene Finikia Formation. The occurrence of microfossils as part of inclusions and within the clay matrix, 

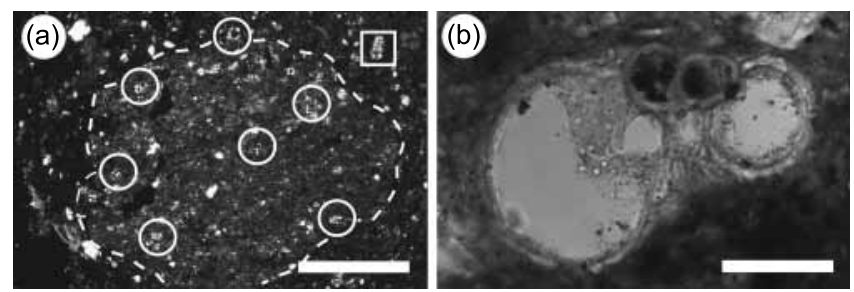

Fig. 6. Microfossils in thin sections of Middle Bronze Age pyxides from Knossos: (a) foraminifera in the clay matrix (square) and within a calcareous marly inclusion (circles) in thin section (crossed polars), scale bar $=500 \mu \mathrm{m}$; (b) close up of globular planktic foraminifer cf. Globigerina in the clay matrix in PPL, scale bar $=50 \mu \mathrm{m}$.

represents different degrees of mixing between these two types of raw materials.

Firing is, perhaps, the most important part of the ceramic production process. The nature of firing and the changes that it brings about determine many of the characteristics of a finished ceramic vessel. Archaeologists employ a wide range of different analytical techniques to reconstruct the specifics of ancient firing, such as the maximum temperature and the type of atmosphere present during the firing process. Crude inferences concerning the severity of the ancient firing process have been made based upon the preservational state of microfossils in archaeological ceramics (e.g. Davis, 1951; Linné, 1957; Brissaud \& Houdayer, 1986; Jansma, 1990). In these examples, ceramics containing well-preserved microfossils were considered to have been low-fired and samples with poorly preserved microfossil assemblages were assumed to have been subjected to a higher degree of firing. Jansma (1990), who analysed the diatom assemblages of Neolithic ceramics from two successive phases at the Dutch site of Schokland, noted a difference in the preservation and abundance of microfossils between these different groups of samples. This he considered to reflect a change in firing technology over time, with the potters achieving higher firing temperatures in the later phase of the site.

By understanding the behaviour of different groups of microfossils during the firing of ceramics and documenting the changes that they undergo during specific thermal conditions, it may be possible to attempt more detailed interpretations of firing technology from their state of preservation in ceramics. Palynomorphs appear to be affected seriously by firing. Firing ceramics above $400^{\circ} \mathrm{C}$ in the presence of oxygen destroys most organic matter, including pollen and spores (Ghosh et al., 2006). However, in ceramics fired in oxygen-poor or reducing conditions, a technological practice used by potters from early times to produce specific decorative effects (Shaw et al., 2001), it has been discovered that palynomorphs can withstand very high temperatures $\left(>1000^{\circ} \mathrm{C}\right)$. The thermal alteration of palynomorphs in geological contexts has been well documented and several indices exist that can be used to estimate the maturity of source rocks for oil and gas formation (Staplin, 1969; Dorning, 1986). Hunt (1996) has applied the thermal alteration index of Staplin (1969) to determine the ancient firing temperature of reduction-fired ceramics from the British Iron Age site of North Furzton. He concluded that these archaeological samples had been fired to a temperature of around $400^{\circ} \mathrm{C}$, equivalent to a thermal maturity of $2+$ to 3 . However, laboratory experiments into the behaviour of palynomorphs during firing suggest that
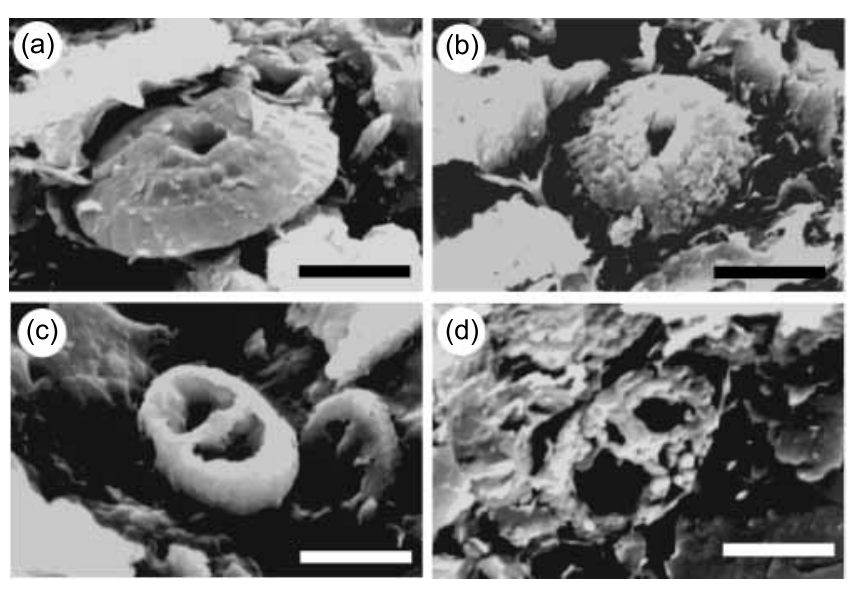

Fig. 7. The degradation of calcareous nannofossils during the firing of experimental ceramic samples, seen in the SEM: (a) Watznaueria barnesae on a broken surface of Gault Clay briquette fired to $600^{\circ} \mathrm{C}$, scale bar $=20 \mu \mathrm{m}$; (b) $W$. barnesae in briquette fired to $800^{\circ} \mathrm{C}$, scale bar $=20 \mu \mathrm{m}$; (c) Zeugrhabdotus erectus in briquette fired to $600^{\circ} \mathrm{C}$ in the SEM, scale bar $=20 \mu \mathrm{m}$; (d) Z. erectus in briquette fired to $800^{\circ} \mathrm{C}$ in the SEM, scale bar $=20 \mu \mathrm{m}$.

this may be an underestimation, as the thermal alteration of pollen, spores and dinoflagellate cysts appears to proceed at a much slower rate in reduction-fired ceramics.

Calcite also undergoes a transformation during firing. This process, which can lead to its subsequent decomposition and recarbonation in pottery is well studied in archaeological ceramic analysis (e.g. Cau et al., 2002), although the precise temperature at which calcite transforms is affected by a range of variables. In order to investigate the alteration of calcareous nannofossils during firing, experimental briquettes of the Albian Gault Clay have been fired at various temperatures in an oxidizing and a reducing atmosphere (Quinn, 1999). These experiments revealed that calcareous nannofossils can be altered at firing temperatures as low as $600^{\circ} \mathrm{C}$ (Fig. 7). The rich calcareous nannofossil assemblages of the test briquettes exhibited a reduction in preservation and abundance as well as predictable changes in their taxonomic composition as they were fired to increasing temperatures. This progressive alteration of calcareous nannofossil assemblages holds significant potential for the interpretation of ancient firing temperatures or archaeothermometry. Similar processes have been observed in real archaeological samples in a study of ceramics from the island of Mozia in Sicily (Quinn et al., 1998), confirming their potential in this respect. Two similar Punic ceramic samples from Mozia, whose firing temperatures were recorded by X-ray diffraction (XRD) as $c .600^{\circ} \mathrm{C}$ and $700^{\circ} \mathrm{C}$, respectively (Alaimo et al., 1997), displayed contrasting calcareous nannofossil preservation. The sample fired to $c .600^{\circ} \mathrm{C}$ revealed an abundant, diverse nannoflora, whereas the higher-fired artefact, which was compositionally very similar, contained only very rare, poorly preserved specimens, indicating that its calcareous nannofossil assemblage had been affected by firing.

\section{DISCUSSION AND CONCLUSIONS}

The studies presented above clearly demonstrate the potential of microfossils and micropalaeontology as a means of addressing several important issues in the analysis of archaeological ceramics. 
As highly distinctive inclusions that reflect the composition of ceramics and the processes that affect them, microfossils are well suited to the interpretation of the origin of ancient ceramic artefacts and the technology involved in their manufacture.

By applying micropalaeontology alongside other compositional, typological and archaeological data, it can be possible to boost significantly the level of interpretation in ceramic analysis. This is particularly true in the area of ceramic provenance. The determination of provenance or origin remains the principal aim of most analytical research on archaeological ceramics and is an area in which micropalaeontology can be used to supplement conventional methods of analysis, such as ceramic petrology and chemistry. It has been shown how micropalaeontology can be applied in several ways to address ceramic provenance on a range of different scales.

The success or resolution of micropalaeontological provenance studies of archaeological ceramics is dependent upon several factors, including the nature of the artefacts and their microfossil assemblages, as well as the raw material diversity of the study area. Clearly, geological heterogeneity is important for discriminating between ceramics from different archaeological sites or regions. Detailed knowledge of local and regional geology is a crucial part of all provenance investigations of archaeological ceramics: geological maps and specialist reports that chart the distribution of major sedimentary deposits and the nature of their microfossil assemblages are a useful source of information. However, more detailed provenance interpretations can be sought by comparing the microfossil assemblages in ancient ceramics with field samples of possible sources of raw materials. Fieldwork should take into account the workability of potential clays or sediments for the manufacture of ceramics, as well as their accessibility in the past.

Of the different groups of microfossils occurring in archaeological ceramics, calcareous nannofossils appear to be one of the most applicable to the determination of provenance. Their small size, ease of preparation and high biostratigraphical resolution make it possible to interpret detailed provenance information from minute samples of archaeological ceramics. Calcareous nannofossils have also been used to provenance several other types of ancient artefacts, including statues (Von Salis, 1995; Fiorentino, 1998), building stone (Thomsen, 1983), mortar (Von Salis, 1995), and even the chalk grounds of medieval paintings (Perch-Nielsen, 1972; Svábenická, 1995; Von Salis Perch-Nielsen \& Plahter, 1995).

In addition to the determination of provenance, micropalaeontology can also make a positive contribution to the investigation of ceramic technology. This application of microfossils is less well studied, yet potentially very informative. Microfossil assemblages in ceramics are sensitive to the various production steps from raw materials to finished vessel, both in terms of their composition and state of preservation. By studying the nature of microfossils in ceramics, and the contexts in which they occur, it can be possible to unravel aspects of an artefact's history, such as the preparation of its raw materials and the way in which it was fired.

Firing is an important aspect of ceramic technology to which micropalaeontology may be successfully adapted. Experiments into the behaviour of calcareous nannofossils (Quinn, 1999) and palynomorphs during firing suggests that the degradation of microfossils during firing takes place in a more or less predictable manner and thus holds potential as a more precise indicator of firing conditions. By documenting these changes in more detail under controlled experimental conditions, it may be possible in the future to develop new archaeothermometric indices that use microfossils to determine the temperatures to which ceramics were subjected in the past.

Unfortunately, not all ceramics contain microfossils. Many ancient ceramic artefacts appear to have been made from unmicrofossiliferous raw materials or clays of residual origin, deriving from igneous or metamorphic rocks. Furthermore, it is likely that some archaeological ceramics, which once contained microfossils, were so badly affected by firing or postdepositional diagenetic processes, that no trace of their assemblages remain. Microfossil assemblages in archaeological ceramics are generally less well preserved, less abundant and less diverse than in geological samples, making their interpretation more difficult. As has been anticipated, there are also several additional sources of potential bias in ceramic microfossil assemblages that are not usually encountered in conventional micropalaeontological analyses (Quinn, 1999).

Despite these drawbacks, the justification for the analysis of microfossils in ceramics or ceramic micropalaeontology (Quinn, $1997 b$ ) is demonstrated clearly by the insights they can provide about the nature of ceramic production and distribution in ancient societies. That detailed micropalaeontological analyses of archaeological ceramics have, so far, taken place in an ad hoc manner is perhaps down to a lack of awareness on the part of archaeologists of the value of microfossils and the types of information that they contain. The highly specialized nature of microfossil taxonomy and the level of experience required to interpret of microfossil assemblages may have also restricted the number of in-depth studies on this phenomenon.

The majority of published analyses on microfossils in ceramics have been the product of interdisciplinary collaboration between archaeologists and micropalaeontologists. In such enterprises it is essential for both analysts to grasp the nature of each other's material and have an appreciation of the contrasting time-scales in which they both operate. Equally, in most cases, micropalaeontological information must be combined with other information, be it typological, chemical or petrographic. By combining their respective skills in this way, micropalaeontologists and archaeologists can incorporate microfossil data successfully within ancient ceramic analysis and bring them to bear on a range of interesting questions.

In presenting the first detailed assessment of ceramic micropalaeontology, it is hoped that this paper has provided a firm foundation for a more thorough approach to the subject. This will hopefully encourage further interdisciplinary research into this a unique and very promising area of applied micropalaeontology.

\section{ACKNOWLEDGEMENTS}

The research summarized in this paper was undertaken as part of the doctoral study of PSQ at the University of Sheffield, with the generous support of the National Environmental Research Council. It forms part of the GEOPRO TMR Research Network project, funded by DGXII of the European Commission through grant ERB-FMRX-CT 98-0165. The authors would 
like to thank Drs Nicolette Hine and Jeremy Young for their positive ideas and support. All specimens figured in this paper are housed at the Department of Archaeology, University of Sheffield.

\section{Manuscript received 20 November 2006 Manuscript accepted 27 April 2007}

\section{REFERENCES}

Alaimo, R., Montana, G. \& Palumbo, V. 1997. La ceramica punica di Mozia (Trapani): Natura delle materie prime e tecnologia di cottura dei reperti della Zona K (VI-V secolo a.C.). Acta Mineralogy Petrography, XL: 1-23.

Alhonen, P. 1971. The stages of the Baltic Sea as indicated by the diatom stratigraphy. Acta Botanica Fennica, 92: 1-18.

Alhonen, P. 1979. Finland. In: Gudelis, V. \& Konigsson, L.K. (Eds), The Quaternary history of the Baltic. University of Upsala, Sweden, 101-113.

Alhonen, P. \& Matiskainen, H. 1980. Diatom analysis of prehistoric pottery sherds - An archaeological evaluation. Nordic meeting of diatomologists, 1980, Lammi, Finland. Geological Society of Finland, 45-62.

Alhonen, P. \& Väkeväinen, L. 1981. Diatom analytical studies of early comb ceramic vessels from Åland. Suomen Museo, 1981: 67-78.

Alhonen, P., Kokkonen, J., Matiskainen, H. \& Vuorinen, A. 1980. Application of AAS, diatom analysis and stylistic studies to Finnish Sub-Neolithic pottery. Bulletin of the Geological Survey of Finland, 52: 193-206.

Brissaud, I. \& Houdayer, A. 1986. Sponge spicules as a characteristic of ancient African pottery from Mali. Journal of Field Archaeology, 13: 357-359.

Brooks, I.P. \& Dorning, K.J. 1997. The assessment of temperature in deliberately heat treated flints and cherts. In: Schild, R. \& Sulgostowska, F. (Eds), Man and flint, Proceedings of the 7th International Flunt Symposium, Warszawa-Ostrowiec Swietokrzyski, Sept. 1995. Institute of Archaeology and Ethnology, Polish Academy of Sciences, Warsaw, Poland, 185-188.

Bryant, V.M. \& Morris, D. 1986. Use of ceramic vessels and grinding implements: The pollen evidence. In: Morris, D. (Ed.), Archaeological investigations at Antelope House. National Park Service Publication in Archaeology: 489-500.

Cau Ontiveros, M.A., Day, P.M. \& Montana, G. 2002. Secondary Calcite in Archaeological Ceramics: evaluation of alteration and contamination processes by thin section study. In: Kilikoglou, V., Hein, A. \& Maniatis, Y. (Eds), Modern Trends in Scientific Studies on Ancient Ceramics: papers presented at the 5th European Meeting on Ancient Ceramics, Athens 1999. BAR International Series, 1011. Archaeopress, Oxford, 9-18.

Davis, A.D. 1951. An Iron Age site on the Chilterns: Pottery containing fossil shells. Antiquaries Journal, 31: 148.

Day, P.M. 1989. Technology and ethnography in petrographic studies of ceramics. In: Maniatis, Y. (Ed.), Archaeometry: proceedings of the 25th international symposium on Archaeometry, Athens 1986. Elsevier, Amsterdam, 139-147.

Day, P.M. 1995. Pottery production and consumption in the Siteia Bay area during the New Palace period. In: Tsipopoulou, M. \& Vagnetti, L. (Eds), Achladia: Scavi e richerche della 'Missione Greco-Italiana in Creta Orientale (1991-1993): 148-175.

Day, P.M., Oren, E.D., Joyner, L. \& Quinn, P.S. 1999a. Petrographic analysis of the Tel Haror inscribed sherd: Seeking provenance within Crete. In: Betancourt, P.P., Karageorghis, V., Laffineur, R. \& Neimeiee, W.-D. (Eds), Meletemata: Studies in Aegean Archaeology Presented to Malcolm H. Wienner as he enters his 65th year, 1. Aegaeum 20, Annales d'Archéologie égéene de l'Université de Liège et UT-PASP, 191-197.

Day, P.M., Kiriatzi, E., Tsolakidou, A. \& Kilikoglou, K. 1999b. Group therapy: a comparison between analyses by NAA and thin section petrography of Early Bronze Age pottery from Central and East Crete. Journal of Archaeological Science, 26: 1025-1036.
Dorning, K.J. 1986. Organic microfossil geothermal alteration and interpretation of regional tectonic provinces. Journal of the Geological Society, London, 143: 219-220.

Driever, B.W.M. 1988. Nannofossil Biostratigraphy and palaeoenvironmental interpretation of the Mediterranean Pliocene. Utrecht Micropalaeontological Bulletin, 36: 1-245.

Edgren, T. 1970. Studier över den snorkeramiska kulturens keramik I Finland. Suomen muinaismuistoyhdistyksen aikakauskirja, 72: 1-159.

Einfalt, H.C. 1978. Chemical and mineralogical investigation of sherds from the Akrotiri excavations. In: Doumas, C. (Ed.), Thera and the Aegean World I. The Thera Foundation, London, 523-527.

Farnsworth, M. 1964. Greek pottery: A mineralogical study. American Journal of Archaeology, 68: 221-228.

Fiorentino, A. 1998. The potential of nannofossil analysis applied to archaeological studies: The case of the Riace's Bronzes. Journal of Nannoplankton Research, 20: 101-103.

Foged, N. 1968. Diatoméerne i nogle Potterskär fra Varanger. Tromso museums skrifter, VII (6): 47-54.

Fortuin, A.R. 1977. Stratigraphy and sedimentary history of the Neogene deposits in the Ierapetra region, eastern Crete. GUA Papers in Geology, Series 1, 8: 1-164.

Fouqué, F.A. 1879. Santorin et ses éruptions. (translation by A. R. McBirney). The John Hopkins University Press, Baltimore and London, 560pp.

Ghosh, R., D'Rozario, A. \& Bera, S. 2006. Can palynomorphs occur in burnt ancient potsherds? An experimental proof. Journal of Archaeological Science, 33: 1445-1451.

Gibson, A.M. 1983. Preliminary results of Diatom analysis of clays and Pre-historic pottery from the Millfield basin. Northern Archaeology, 4: $33-44$.

Groenman-Van Waateringe, W. \& Jansma, M.J. 1968. Diatom analysis. In: Van Es, W. A. (Ed.). Paddepoel, excavations of frustrated terps, 200 BC-250 AD. Paleohistoria, 14: 286.

Hein, A., Day, P.M., Quinn, P.S. \& Kilikoglou, V. 2004. Geochemical diversity of Neogene clay deposits in Crete and its implications for Provenance studies of Minoan pottery. Archaeometry, 46: $357-384$.

Horrocks, M., Jones, M.D., Beever, R.E. \& Sutton, D.G. 2002. Analysis of plant microfossils in prehistoric coprolites from Harataonga Bay, Great Barrier Island, New Zealand. Journal of The Royal Society of New Zealand, 32: 617-628.

Hunt, C.O. 1996. Palynological evidence for ceramic sources and firing temperatures: Iron Age sherds from Milton Keynes, UK. Program and Abstracts, IX IPC Meeting, Houston, Texas, USA. International Federation of Palynologists, Houston, 69.

Håkansson, H. 1997. Diatom analysis on resolved sherds. In: Stilborg, O. (Ed.), Shards of Iron Age Communication: A ceramological study of internal structure and external contacts in the Gudme-Lundeborg Area, Funen during the Late Roman Iron Age. Monographs on Ceramics. Keramiska Forskningslaboratoriet, Lunds Universitet, Sverige, 241-245.

Håkansson, H. \& Hulthén, B. 1986. On the dissolution of pottery for Diatom studies. Norwegian Archaeological Review, 19: 34-38.

Håkansson, H. \& Hulthén, B. 1988. Identification of Diatoms in Neolithic pottery. Diatom Research, 3: 39-45.

Jansma, M.J. 1977. Diatom analysis of pottery. In: Beck, B., Brandt, R. \& Groemann-Van Waaterringe, W. (Eds), Ex horreo. Society Ex horreo, Amsterdam, 77-85.

Jansma, M.J. 1981. Diatom analysis from coastal sites in the Netherlands. In: Brothwell, D. \& Dimbleby, G. (Eds), Environmental Aspects of Coasts and Islands. BAR International Series, 94: 145-162.

Jansma, M.J. 1984. Diatom analysis of prehistoric pottery. In: Mann, D.G. (Ed.), Proceedings of the 7th International Diatom Symposium at Koenigstein. O. Koeltz, Koenigstein, 529-536.

Jansma, M.J. 1990. Diatoms from a Neolithic excavation on the former island of Schokland, Ijselmeepolders, the Netherlands. Diatom Research, 5: 301-309.

Leroi-Gourhan, A. 1975. The flowers found with Shanidar IV. A Neanderthal burial in Iraq. Science, 190: 562-564.

Linné, S. 1957. Technical secrets of American Indians: The Huxley Memorial Lecture 1957. Journal of the Royal Anthropological Institute of Great Britain and Ireland, 87: 149-163. 
MacGillivray, J.A., Day, P.M. \& Jones, R.E. 1988. Dark-Faced Incised Pyxides and Lids from Knossos: Problems of date and origin. In: French, E.B. \& Wardle, K.A. (Eds), Problems in Greek Prehistory: Papers presented at the centenary conference of the British School of Archaeology at Athens, Manchester, April 1986. Bristol Classical Press, Bristol, 91-94.

Magid, A.A. \& Krzywinski, K. 1988. Extraction of Pollen from Pottery. Arkeologiske Skrifter, 4: 196-204.

Martini, E. 1971. Standard Tertiary and Quaternary calcareous nannoplankton zonation. In: Farinacci, A. (Ed.), Proceedings of the second Planktonic Conference, Roma. Edizioni Tecnoscienza, Rome, 739-785.

Matiskainen, H. \& Alhonen, P. 1984. Diatoms as indicators of provenance in Finnish sub-Neolithic pottery. Journal of Archaeological Science, 11: 147-157.

Montana, G., Mommsen, H., Iliopoulous, I., Schwedt, A. \& Denaro, M. 2003. The petrography and chemistry of thin walled ware from a Hellenistic Roman site at Segesta (Sicily). Archaeometry, 45: 375-387.

Oren, E.D., Oliver, J.P., Goren, Y., Betancourt, P.P., Myer, G.H. \& Yellin, J. 1996. A Minoan Graffito from Tel Haror (Negev, Israel). Cretan Studies, 5: 91-118.

Perch-Nielsen, K. 1972. Fossil coccoliths as indicators of Late Cretaceous chalk used in Medieval art. Universitets Oldsaksamling. Lrbrok, 1970-71: 161-169.

Quinn, P.S. 1997a. Book review: 'Scientific Methods in Underwater Archaeology' by I. Vuorela. Marine Micropaleontology, 30: 346-350.

Quinn, P.S. 1997b. Ceramic Micropalaeontology. The Old Potters Almanack, 5: 5.

Quinn, P.S. 1999. A note on the behavior of nannofossils during the firing of ceramics. Journal of Nannoplankton Research, 21: 31-32.

Quinn, P.S. \& Day, P.M. 2007. Calcareous microfossils in Bronze Age Aegean ceramics: illuminating technology and provenance. Archaeometry, 49: doi:10.1111/j.1475-4754.2007.00335.X.

Quinn, P.S., Alaimo, R. \& Montana, G. 1998. Nannofossil analysis of ceramics and probable raw materials from an ancient Punic kiln site on the island of Mozia, western Sicily. Journal of Nannoplankton Research, 20: 85-87.

Riley, J.A. 1981. Petrological examination of coarse-ware stirrup jars from Mycenae. Annual of the British School at Athens, 76: 335-340.

Riley, J.A. 1982. The petrological analysis of Aegean ceramics. In: Freestone, I.C., Johns, C. \& Potter, T. (Eds), Current Research in Ceramics: Thin-Section Studies. British Museum Occasional Paper, 32: $1-7$.

Riley, J.A. 1983. The contribution of ceramic petrology to our understanding of Minoan society. In: Krzyszkowska, O. \& Nixon, L. (Eds), Minoan Society, Proceedings of the Cambridge Colloquium 1981. Bristol Classical Press, Bristol, 283-292.

Shaw, J.W., van der Moortel, A., Day, P.M. \& Kilikoglou, V. 2001. A Late Minoan IA ceramic kiln from South-Central Crete: function and pottery production. Hesperia Supplement, 30. American School of Classical Studies, New York, 171pp.

Smith, A.H.V. 1997. Provenance of Coals from Roman Sites in England and Wales. Britannia, 28: 297-324.

Spaak, P. 1983. Accuracy in correlation and ecological aspects of planktonic foraminiferal zonation of the Mediterranean Pliocene. Utrecht Micropalaeontological Bulletin, 18: 1-159.

Staplin, F.L. 1969. Interpretation of thermal history from color of particulate organic matter: a review. Palynology, 1: 9-17.
Stilborg, O.H. 1997. Shards of Iron Age Communication: a ceramological study of internal structure and external contacts in the GudmeLundeborg Area, Funen during the Late Roman Iron Age. Monographs on Ceramics. Keramiska Forskningslaboratoriet, Lunds Universitet, Sverige, 326pp.

Svábenická, L. 1995. Late Maastrichtian nannofossils in the material of Master Theodoricus' paintings (14th century Bohemia). In: Flores, J.A. \& Sierro, F.J. (Eds), Proceedings of the 5th INA Conference, Salamanca. Universidad de Salamanca Press, Salamanca, 279-287.

Thomsen, E. 1983. Byginingsstenen I Grenåegens kalkstenskrker. Hikuin, 9: 65-78.

Troja, S.O., Cro, A., Gueli, A.M., La Rosa, V., Mazzolen, P., Pezzino, A. \& Romeo, M. 1996. Characterisation and thermoluminescence dating of archaeological pottery sherds from Milena. Archaeometry, 38: $113-128$.

Vaughan, S.J. 1990. Petrographic analysis of the Early Cycladic wares. In: Hardy, D.A. (Ed.), Thera and the Aegean World III, vol. I. Thera Foundation, London, 470-487.

Vaughan, S.J., Kilikoglou, V. \& Papagiannopoulou, A. 1995. An interdisciplinary study of Middle Cycladic White Wares from Akrotiri on Thera. Proceedings of the Materials Research Society Symposium, 352: 445-452.

Vidakis, M., Fortuin, A.R., Papzeti, E. \& Skourtsi-Koroneou, V. 1993. Geological Map of Greece, I:50000, Ierapetra Sheet. Institute of Geology and Mining Exploration, Athens, Greece.

Von Salis, K. 1995. Calcareous Nannofossils in the Arts. Journal of Nannoplankton Research, 17: 88-90.

Von Salis Perch-Nielsen, K. \& Plahter, U. 1995. Analyses of fossil coccoliths in chalk grounds of medieval art in Norway. Norwegian Medieval Altar Frontals and Related Material, Papers from the conference in Oslo, 16-19 December, 1989. Acta ad Archaeologiarn Artium Pertinentia Volumen, XI. Giorgio Bretschneider, Rome, $145-155$.

Vourela, I. 1994. Two Examples on Pollen Analysis as a Key to the History of a Wreck. In: Vuorela, I. (Ed.), Scientific Methods in Underwater Archaeology, Proceedings of a European Seminar Held at the Zoological Field Station, Tvarminne, Finland, October 15-18, 1992. PACT, Journal of the European Network of Scientific and Technical Co-operation for the Cultural Heritage, 47: 91-94.

Warren, P. 1969. An Early Bronze Age potter's workshop in Crete. Antiquity, 43: 224-227.

Warren, P. 1972. Myrtos: An Early Bronze Age Settlement in Crete. British School at Athens Supplementary Volume, 7.

Whitbread, I.K. 1995. Greek Transport Amphorae: a petrological and archaeological study. Fitch Laboratory Occasional Paper, 4. British School at Athens, 453pp.

Whitelaw, T.M., Day, P.M., Kiriatzi, E., Kilikoglou, V. \& Wilson, D.E. 1997. Ceramic Traditions at EMIIB Myrtos, Fournou Korifi. In: Laffineur, R. \& Betancourt, P.P. (Eds), TEXNH: Craftsmen, Craftswomen and Craftsmanship in the Aegean Bronze Age. Liège, Aegaeum, 265-275.

Williams, D.F. 1978. A petrological examination of pottery from Thera. In: Doumas, C. (Ed.), Thera and the Aegean World I. Thera Foundation, London, 507-514.

Zachariasse, W.J. 1975. Planktonic foraminiferal biostratigraphy of the late Neogene of Crete (Greece). Utrecht Micropalaeontological Bulletin, 11: 1-171. 